\title{
Examining indicators for effective studying - The interplay between student integration, psychological flexibility and self-regulation in learning
}

\author{
Henna ASIKAINEN \\ Centre for University Teaching and Learning (HYPE), University of Helsinki
}

(Received on February 1, 2018; Accepted on March 15, 2018)

\begin{abstract}
Prolonged study times and dropouts from university studies have created a need to examine more ways to support students' studying. This study aims to examine the relationship between the self-regulated learning, psychological flexibility and student integration comprising teacher and student interaction, students' commitment to studying as well as the relationship of these aspects to study progression. The participants of this study were 117 theology students. Items measuring student integration were first analysed with factor analysis. The relationship between student integration, psychological flexibility, self-regulated learning and study progression was analysed with correlation analyses and Structural Equation Modelling (SEM). The results show that psychological flexibility is related to study progression, self-regulated learning and student integration. The effect of self-regulated learning and student integration to study progression was not significant. This study suggests that students' way of coping with negative thoughts and emotions should be taken into account when considering learning and teaching.
\end{abstract}

Keywords: student integration, psychological flexibility, self-regulation.

Examinar indicadores para un estudio efectivo - Interacción entre la integración de los estudiantes, la flexibilidad psicológica y la autorregulación en el aprendizaje

RESUMEN: El prolongado tiempo de estudio y el abandono de los estudios universitarios han generado la necesidad de estudiar otras maneras de apoyar el estudio de los estudiantes. El presente estudio tiene como objetivo examinar la relación entre el aprendizaje autorregulado, la flexibilidad psicológica y la integración estudiantil, que comprende la interacción docente-estudiante, su compromiso para estudiar así como su relación con el progreso de estudio. En este estudio participaron 117 estudiantes de Teología. Los ítems que miden la integración estudiantil se analizaron mediante análisis factorial. Se analizó la relación entre integración estudiantil, flexibilidad psicológica, aprendizaje autorregulado y progreso de estudio mediante análisis de correlación y Modelación de Ecuación Estructural (SEM). Los resultados muestran que la flexibilidad psicológica está relacionada con el progreso de estudio, el aprendizaje autorregulado y la integración de los estudiantes. El efecto del aprendizaje autorregulado y la integración de los estudiantes para estudiar el progreso de estudio no fue significativo. Este estudio sugiere que la forma de los estudiantes de hacer frente a los 
pensamientos negativos y las emociones deben tenerse en cuenta al considerar el aprendizaje y la enseñanza.

Palabras clave: integración estudiantil, flexibilidad psicológica, autorregulación.

Correspondencia: Asikainen, Henna. Centre for University Teaching and Learning (HYPE), University of Helsinki, Viikinkaari 2, P.O. Box 65, 00014 University of Helsinki.Tfno: +358 503111 94. Email: henna.asikainen@helsinki.fi.

\section{Introduction}

In the changing, modern society, universities are facing challenges meeting the demands of government and the society in effectiveness. Students' progression in their studies has become one of the factors measuring efficiency as students need to study effectively in optimal study time. However, prolonged study times and delays in graduation have become growing concerns internationally (OECD, 2009). In addition, students are feeling worse than before and they experience more mental health problems (Hunt \& Eisenberg, 2010; Storrie, Ahern, \& Tuckett, 2010). These problems can lead to drop-outs and delays in studies. Thus, it is crucial to develop teaching and learning to help the students to study effectively and at the same time promote their well-being.

Student integration is considered to be crucial to students effective studying and to avoid student dropouts (Pascarella \& Terenzini, 2005). When students fail to integrate into college it will make students more likely to drop out (Tinto, 1975). Student integration to the university can be assumed to be an emotional experience as the learning environment promotes the development of expertise and a lot of different kind of people with different backgrounds come together (Cartney \& Rouse, 2006). Thus, emotions can play an important role in how the students integrate to the university. For example, anxiety rising from the new situations can make students to withdraw for unconfutable situations or address these situations despite of the anxiety (Boekaerts, Pintrich, \& Zeider, 2000). However, emotional aspects and how students cope with their emotions and how it affects their integrations has been understudied. Furthermore, universities have a learning culture which requires independence and responsibility from students. Thus, self-regulated learning is an important aspect in university studies (Vermunt \& Verloop, 1999). The purpose of this study is to examine the interplay that students integration, psychological flexibility and self-regulation have and how they are related to study progression at the university.

\section{Student integration}

Students' integration into their studies has been widely explored (Borglum \& Kubala, 2000; Deil-Amen, 2011; Pascarella, Wolniak, \& Pierson, 2003; Tinto, 1993). When exploring student integration, the most cited model is Tinto's (1975) model of student persistence. This model highlights academic and social integration as the most important factor explaining student persistence. Academic integration can be defined as academic performance and progress, self-perceptions and the belief of staff commitment to teaching and supporting students and social integration as self-esteem and the quality of relationships with teachers and peers within the academic environment, as well as financial considerations (Freeman, (c) Psy, Soc, \& Educ, 2018, Vol. 10(2) 
deMarrais, Preissle, Roulston, \& St. Pierre, 2007; Hagenauera \& Voletb, 2014; Halawah, 2006). When students fail to integrate into college, both socially and academically, it will make students more likely to drop out (Tinto, 1975). Tintos (1975) model takes into account number of individual factors such as students' personality or family background but lacks other psychological aspects such as student emotions or coping with negative feelings or thoughts which are important factors related to students learning and studying (Pekrun, Goetz, Titz, \& Perry, 2002). However, recent studies have shown that dealing with negative thoughts and uncertainty have an important role in influencing study progression at the university level (Asikainen, Hailikari, \& Mattsson, 2017). Thus, it can be suggested that students' emotions and coping with them is related to the way they integrate to the university.

\section{Psychological flexibility}

One way to conceptualise students' way of dealing with their emotions is psychological flexibility. Psychological flexibility describes people's ability to be connected with the present, and regulate their thoughts and actions despite the unpleasant feelings or thoughts they might have (Chawla \& Ostafin, 2007; Hayes, Luoma, Bond, \& Masuda, Akihiko,\& Lillis, Jason, 2006). The concept psychological flexibility stems from the concept of experimental avoidance which is originated in Acceptance and Commitment Therapy (Hayes et al., 2006). Experimental avoidance can be defined as unwillingness to experience or accept feelings, thoughts or memories that are negative and which are associated with negative experiences (Hayes \& Smith, 2005). Psychological flexibility can be regarded as an alternative or opposite approach. That is to say, psychologically flexible people act more based on their own values and accept the negative thoughts or feelings such as anxiety or stress by approaching these situations mindfully (Bond, Joda, \& Guenole, 2013). Thus, the student is able to act based on his or her own values despite the fact that it makes the student anxious or by observing the moment and excepting the negative feelings they might have (Bond et al., 2013; Sloan, 2004) (Kashdan \& Rottenberg, 2010). Components of Acceptance and Commitment therapy have been widely used in different context to improve participants performance (Eisenbeck, 2016; Flaxman, Bond, Livheim, \& Hayes, 2013; Hayes et al., 2006).

Psychological flexibility has been shown to be an important element in improving performance and well-being at work (Flaxman et al., 2013). Yet, its importance has not been fully explored in the university context. In a recent study, psychological flexibility has been shown to be related to study progression and positive emotions in learning at the university context (Asikainen et al., 2017). In addition to psychological flexibility, the central role of self-regulation in effective studying has been widely acknowledged (Hailikari \& Parpala, 2014; Heikkilä \& Lonka, 2006; Postareff, Lindblom-Ylanne, \& Parpala, 2014). Tradition of self-regulated learning emphasises students' actively learning and constructing their own meanings, goals and strategies (Pintrich, 2004) and may be defined as planning, monitoring and evaluating one's own learning process in order to attain a goal (Vermunt, 1996). Thus, self-regulated learners are generally characterized as active learners who regulate their own learning processes in many different ways (Schunk \& Zimmerman, 2012). In the present study, the focus is on self-regulated learning and the theoretical framework is based on Vermunts' (1996) research on self-regulated learning where self-regulation is seen as a way for students' to plan, monitor and control their learning. 
In previous studies, self-regulated learning has a close connection to how students' experience and regulate emotions in studying. According to Boekarts' (2011) Dual Processing SelfRegulation students who appraise negative emotions during a learning situation can have different interpretations of the learning situation: those students who feel they can deal with the mismatch between goals and the learning situation continue to work, but some students may interpret the negative feelings as a threat to well-being and remove from the situation (Boekarts, 2006). Thus, it can be suggested that psychological flexibility would influence students learning processes. Furthermore, in addition to study progression and emotion regulation, self-regulation has been found to have an important role in student integration (Lee, Choi, \& Kim, 2013).

The purpose of this study is to explore the role of self-regulated learning and psychological flexibility in student integration and their relation to study progression at the university level. The hypothesis is that psychological flexibility and self-regulation affect student integration as well as study progression.

\section{Method}

\section{Context}

This study was carried out at the Faculty of Theology, University of Helsinki, Finland. The faculty is highly research-oriented and possesses two research centres of excellence. The teaching at these faculties is non-confessional and students come from various backgrounds. The faculty offers an education for students who wish to become pastors in the EvangelicalLutheriran church but trains students also as experts for universities, research institutions, schools and different organisations. Over half of the students do not study to become a pastor. At the faculty, about 170 new students start their studies every year and there are about 1500 studying at the faculty. In the context of theology, the delay of studies have been found to be a problem. It has been found that under 15 per cent of the students graduate as Masters in expected five years ( 3 year Bachelor +2 years Masters) and for over half of the students it takes longer than 7 years to graduate. In addition, it has been shown that theology students' may lack proper self-regulation skills. In a study done in different faculties at a university, it was shown that most theology students applied deep approach to learning but were quite unorganised in their studying. That is to say the students were interested of the subject matter and wanted to really understand, but lacked time management and organising skills in their studying (Parpala, Lindblom-Ylänne, Komulainen, Litmanen, \& Hirsto, 2010). For theology students, values are considered as important for life and students' own values in life are also a reason for entering theological education (Hirsto, 2012). A critical exploration of religion and one's own set of values can cause different kind of emotions that the students need to cope with. In addition, theology students have been found to be rather optimistic about their social support in achievement situation in studies and believe in their own success (Hirsto, 2012). Thus, it could be assumed that social integration of students would be quite successful at the university level. 


\section{Participants}

An electronic questionnaire was send to all the students in the Faculty of Theology, at the University of Helsinki through email and Facebook page for theology students at fall 2015. Altogether 127 students from the faculty of Theology voluntarily participated in this study. A total of 10 students were not included to the analysis because their identification information was not found and, thus, study progression could not be added. Thus, the final data had 117 participants. The age of the participants ranged between 19 and $62(\mathrm{M}=34,21, \mathrm{~s}=12,57)$. A large amount of students start their studies at the faculty at an older age. Thus, the age range resembles the target group quite well, but older age students are a little bit overrepresented. Of the participants, $67 \%$ were female and $31 \%$ male, one student chose other gender. About 60 percent of the students studying in the Faculty of Theology are female, thus, they were a bit overrepresented in the data. The stage of study varied a lot. A total of $6 \%$ of the students were first-year students, $19 \%$ second-year students, $16 \%$ third-year students, $20 \%$ fourth-year students, $10 \%$ fifth-year students and the rest of the students $(29 \%)$ had started their studies in 2010 or earlier.

\section{Measures}

The questionnaire consisted of sections which measured students' self-regulated learning, psychological flexibility and student integration. The scales were seven-level Likert-type items in which $1=$ never true and $7=$ always true.

The items concerning student integration were adapted from a questionnaire (Pascarella \& Terenzini, 1980), based on Tinto's (1975) theoretical model, and were translated and modified into Finnish context by Lähteenoja (2010). The scales included in this study were Peer group interaction, Interaction with faculty, Faculty concern for student development and Instructional and goal commitment.

Psychological flexibility was measured based on the work-related acceptance and action questionnaire (WAAQ) (Bond et al., 2013) which has been developed for a Finnish context (Nieminen, Asikainen \& Hailikari, 2014). Self-regulation was measured with a seven-item selfregulation scale from the Inventory of Learning styles (Vermunt \& Van Rijswijk, 1988). The study progression was measured by accumulation of credits (ECTS) from the last academic year.

\section{Analyses}

Exploratory factor analysis with principal axis factoring and oblimin rotation was conducted to the items measuring student integration. Oblique rotation was chosen because it could be assumed that the items measuring student integration would correlate with each other.

The sum scales measuring self-regulation and psychological flexibility were formed based on previous research and reliabilities. The items measuring self-regulation and psychological flexibility can be seen in Table 1. The relationship between self-regulation, academic emotions 
and psychological flexibility as well as their relation to study success and study pace was measured with Pearson's correlation and path analyses using Amos.

Table 1. Scales measuring psychological flexibility and self-regulation and their reliabilities

\begin{tabular}{|c|c|c|}
\hline \multicolumn{3}{|l|}{ Scale } \\
\hline Psychological. flexibility & Items & $\alpha$ \\
\hline & $\begin{array}{l}\text { I can study effectively even if I have personal worries } \\
\text { I can admit mistakes I have made and still be successful in my } \\
\text { studies } \\
\text { I can study effectively even if I am nervous } \\
\text { My worries do not prevent me from succeeding in my studies } \\
\text { I can do what is required of me in my studies, despite any } \\
\text { emotions I } \\
\text { may be having } \\
\text { I can work effectively even when I have doubts about myself } \\
\text { My thoughts and emotions do not create an obstacle to studying }\end{array}$ & .89 \\
\hline \multicolumn{3}{|l|}{ Self-regulation } \\
\hline & $\begin{array}{l}\text { When I am studying, I also pursue learning goals that have not } \\
\text { been set by the teacher but by myself } \\
\text { When I have difficulty grasping a particular piece of subject } \\
\text { matter, I try to analyse why it is difficult for me } \\
\text { To test my learning progress, I try to answer questions about the } \\
\text { subject matter which I make up myself. } \\
\text { In addition to the syllabus, I study other literature related to the } \\
\text { content of the course. } \\
\text { If I do not understand a study text well, I try to find other } \\
\text { literature about the subject concerned. } \\
\text { I do more than I am expected to do in a course. }\end{array}$ & .78 \\
\hline
\end{tabular}

\section{Results}

The final factor solution concerning the items measuring student integration had three factors. The factors were named F1) Teacher interaction and support, F2) Student interaction, F3) Commitment. The factor loadings can be seen in Table 2. Cronbach's alphas for the factors measuring student integration were good and ranged between .74-.88. Cronbach's alpha concerning the self-regulation scale was 0.81 and items measuring psychological flexibility 0.90 which indicates a good consistency. 
Table 2. Factor structure of the items measuring student integration

\begin{tabular}{|c|c|c|c|}
\hline Items & F1 & $\mathrm{F} 2$ & F3 \\
\hline 1. The teachers I have had contact with are generally interested in students & ,766 & ,090 &, 060 \\
\hline 2. The teachers I have had contact with are generally very good teachers & ,765 &,- 052 &,- 022 \\
\hline $\begin{array}{l}\text { 3. My interaction with teachers have had a positive influence on my personal } \\
\text { growth and interest in ideas }\end{array}$ & ,721 &, 244 &,- 105 \\
\hline $\begin{array}{l}\text { 4. I am satisfied with the opportunities to meet and interact informally with } \\
\text { teachers. }\end{array}$ & ,645 &,- 004 &, 151 \\
\hline 5. Teachers encourage and support me in my studies & ,884 & 029 &,- 086 \\
\hline $\begin{array}{l}\text { 6. Since coming to this university I have developed a personal relationship with at } \\
\text { least one teacher }\end{array}$ & ,656 &,- 077 &,- 010 \\
\hline 7. Most teachers I have had contact with are generally interested in teaching & ,645 &,- 014 & ,076 \\
\hline 8. I feel that I am a part of Helsinki University community & ,077 &,- 044 & ,801 \\
\hline 9. I am proud of myself for studying in the University of Helsinki &,- 041 &, 114 & ,692 \\
\hline $\begin{array}{l}\text { 10. Since coming to this university I have developed close personal relationships } \\
\text { with other students }\end{array}$ & 020 & ,814 & ,007 \\
\hline $\begin{array}{l}\text { 11. The student friendships I have developed at this university have been personally } \\
\text { satisfying }\end{array}$ &, 028 & ,877 & ,098 \\
\hline $\begin{array}{l}\text { 12. My interpersonal relationships with other students have had a positive influence } \\
\text { on my intellectual growth and interest in ideas }\end{array}$ &,- 004 & ,793 &,- 007 \\
\hline
\end{tabular}

\section{Correlation analyses}

The correlation analysis showed that all the components measuring integration were statistically significantly related to each other. In addition, self-regulation and psychological flexibility were correlated positively with each other and psychological flexibility correlated positively with scales measuring student integration. Self-regulation was related to interaction with teachers, but the relationship to commitment and peer interaction was not statistically significant. Furthermore, psychological flexibility and self-regulation were positively related to study progression but there were no statistically significant relations between study progression and student integration. The correlations can be seen in Table 3 .

Table 3. Correlations between the variables.

\begin{tabular}{lcccccc}
\hline Scale & & & & & & \\
\hline & PI & IT & Co & PF & SR & SP \\
\hline PI Peer group interaction & $\mathbf{1}$ & & & & & \\
IT Interaction with teachers & $\mathbf{4 1}^{* *}$ & $\mathbf{1}$ & & & & \\
Co Commitment. & $\mathbf{. 4 0}^{* *}$ & $\mathbf{. 3 2 * *}$ & $\mathbf{1}$ & & & \\
PF Psychological flexibility & $\mathbf{. 3 8}^{* *}$ & $\mathbf{. 5 1 * *}$ & $\mathbf{. 2 4 * *}$ & $\mathbf{1}$ & & \\
SR Self-regulation & .13 & $\mathbf{. 3 8 * *}$ & .09 & $\mathbf{. 3 3}^{* *}$ & $\mathbf{1}$ & \\
SP Study progression & .10 & .16 & -.06 & $\mathbf{. 4 2}^{* *}$ & $\mathbf{. 2 3}^{*}$ & $\mathbf{1}$ \\
\hline
\end{tabular}


The model was build based on the hypotheses about psychological flexibility and selfregulation influencing the components measuring student integration. In the model, factors measuring student integration were intervening variables between self-regulated learning and psychological flexibility as well as study progression. Connections between the scales measuring student integration and study progression were not good. Thus, only a connection between teacher integration and study progression was left to the model. The model fitted the data well $\left(\chi^{2}=3.40 \mathrm{p}=.18\right.$, RMSEA $\left.=0.078, \mathrm{CFI}=0.99\right)$. The path model showed that psychological flexibility was most strongly related to all the components of integration $(\mathrm{p} \leq 0.01)$. Self-regulation was not so strongly related to integration except mildly to Interaction with teachers $(\mathrm{p}=.08)$. The components measuring student integration as well as selfregulation where poorly related to study progression, but psychological flexibility was quite strongly related to it $(\mathrm{p}<0.001)$. The model can be seen in Figure 1.

Figure 1. The structural equation model of the relationship between psychological flexibility, self-regulated learning and student integration.

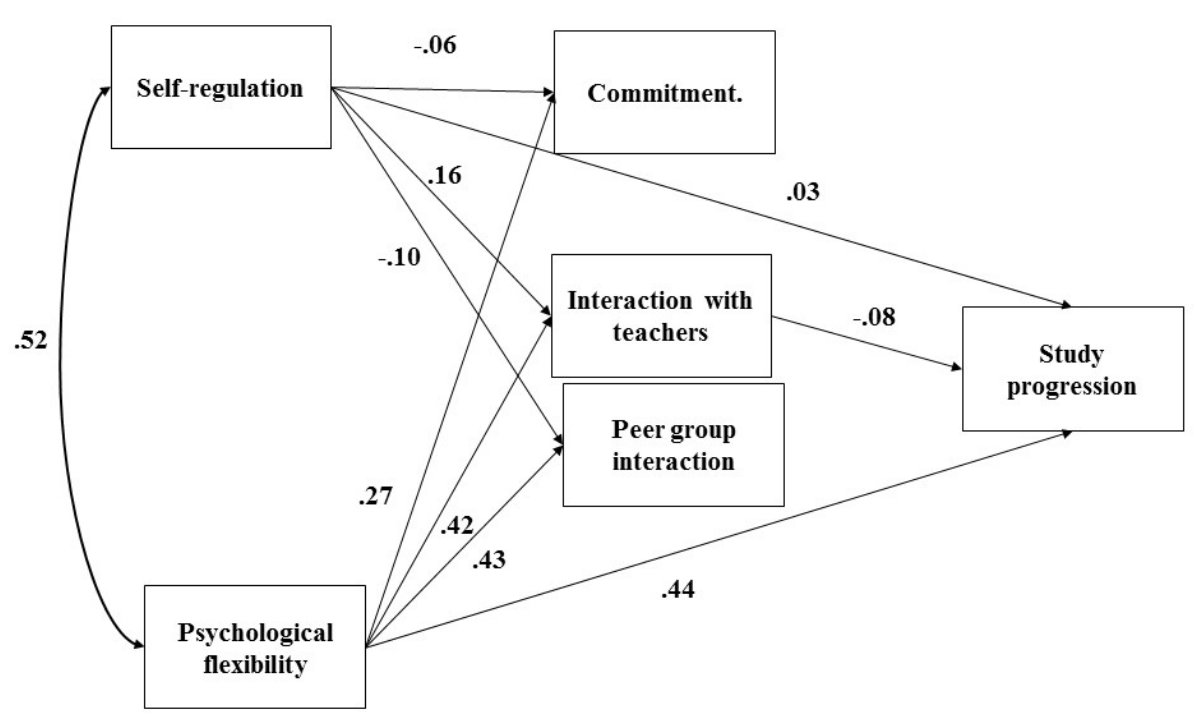

\section{Discussion}

The purpose of this study was to explore the relationship between student integration, selfregulation, psychological flexibility and study progression. It was hypothesized that selfregulation and psychological flexibility would be associated with student integration and all three would have an effect on study progression.

The present study clearly showed that psychological flexibility is related to student integration a.k.a their perceptions of interaction and support of teachers, peer group interaction and commitment. That is to say, the way students deal with their negative thoughts and feelings affects the way they experience the interaction with teachers and other students as well as their commitment to studies. Earlier research has shown that anxiety rising from new situations can make students to either withdraw from unconfutable situations or address these situations despite of the anxiety (Boekaerts et al., 2000). It has also been suggested that suppressing emotions can 
have consequences such as depression and feelings of loss of control (Gross \& Thompson, 2007). Thus, it can be assumed that lacking psychological flexibility can make committing to studies more difficult and make students experiences of teacher and peer support more negative.

The present study also showed that psychological flexibility was related to study progression. That is to say, students who consider themselves as capable of studying despite the possible negative thoughts and emotions progress better in studies. This strengthens the fact that emotions have an important role in learning and studying (Pekrun et al., 2002). Psychological flexibility has not been studied at university context very much in relation to study progression, but this result is in line with earlier research which has shown it to be a strong predictor of study pace (Asikainen et al., 2017). Furthermore, in the present study self-regulated learning was not so much related to study progression. Surprisingly, students' experiences of interaction with teachers and students as well as commitment were also unrelated to study progression which normally have been considered as being important factor influencing it (Hailikari \& Parpala, 2014; Heikkilä \& Lonka, 2006) Although there was a statistically significant correlation between self-regulated learning and study progression, the connection became weaker in the SEM-model. That is to say, the way students deal with their negative thoughts and feelings has a greater impact on study progression than how they regulate their learning, how they experience interaction with teachers and students or their commitment to studying. This result brings interesting aspects to the discussion which emphasises the importance of selfregulation in studies (Hailikari \& Parpala, 2014; Heikkilä \& Lonka, 2006).

The relationship between self-regulated learning and student integration was not so evident. Earlier research has shown a positive relation between self-regulated learning and social integration (Sidelinger, Bolen, McMullen, \& Nyeste, 2015) and sense of belongingness in the study context (Won, Wolters, \& Mueller, 2017). In addition, the present study showed that study progression was not related to components of student integration. That is to say, the support that students experienced from peers and teachers as well as their commitment to studying was not related to study progression in our study. This is contradictory to earlier studies which suggest that integration to the university or collage would engage students to studying (Pascarella \& Terenzini, cop. 2005). In the context of theology, students have been found to be rather optimistic about their social support in achievement situation in studies and believe in their own success (Hirsto, 2012). Thus, it may be the fact that they experience the interaction quite positively despite of their study progression. More research on this issue is needed.

\section{Limitations}

There were several limitations to our study. One limitation of our study was the small sample size. Very small amount of students from the Faculty of Theology, less than 10 percent, answered the questionnaire. Thus, the sample cannot be considered as very representative based on its size. However, if you consider the gender and age of the participants, the sample can be considered quite representative despite of the small numerus. In addition, the purpose of this study was to explore the role of psychological flexibility in student integration and study progression and the study was mostly in line with the hypotheses and showed the strong relationship between psychological flexibility and study progression also found in previous 
studies (Asikainen et al., 2017). Nevertheless, more research should be done to support this finding. In addition, the sample size can be considered quite small for Structural Equation Modelling. Although, the indexes which avoid issues of sample size such as RMSEA can be considered acceptable in this model (Holstein \& Gubrium, 2004).

The factor analysis can also be considered challenging. The questionnaire concerning student integration did not work properly in the present study. There were cross loadings and poor communalities. The small sample size can be one reason for this. Furthermore, the present study only focused on self-regulation in learning but did not consider external regulation and lack of regulation. The relationship between problems in regulation in learning and coping with negative emotions should also be explored in future research. Furthermore, the measurement of student integration concentrates mainly on components of social integration. Components measuring academic integration were not included in this study. The present study brings some insight to the relationship but the relationship between student integration, psychological flexibility, self-regulated learning and study progression should be more thoroughly examined.

\section{Practical implications}

The present study suggests the importance of considering students' negative feelings and thought in learning and studying and how they cope with these as part of university learning and teaching. Key components in promoting psychological flexibility are acceptance of emotions, values and the present situation which has been found to promote psychological flexibility in the work place (Bond, Flaxman, van Veldhoven, \& Biron, 2010). Students should be encouraged to share their feelings and be made aware of the emotions that are encountered during learning and studying among peers and in teaching. New ways of promoting students ability to deal with their thought and feelings should be developed as part of teaching in higher education. More reserach on how this could be done is needed. There has been some evidence that students' well-being can be improved through an online intervention based on improving psychological flexibility (Räsänen, Lappalainen, Muotka, Tolvanen, \& Lappalainen, 2016). Also, in the working-life setting, it has been shown that improving psychological flexibility can significantly improve performance (Flaxman et al., 2013) However, we still would need further research on how to support it better among university students and how to promote these skills as part of teaching.

\section{References}

Asikainen, H., Hailikari, T., \& Mattsson, M. (2017). The interplay between academic emotions, psychological flexibility and self-regulation as predictors of academic achievement. Journal of further and Higher Education, doi:10.1080/0309877X.2017.1281889

Boekaerts, M., Pintrich, P. R., \& Zeider, M. (2000). Handbook of self-regulation. San Diego, Calif: Academic Press.

Bond, F., Flaxman, P., van Veldhoven, M., \& Biron, M. (2010). The impact of psychological flexibility and acceptance and commitment therapy (ACT) on health and productivity at work. In J. Houdmont, \& S. Leka (Eds.), Contemporary occupational health psychology: Global perspectives on research, education, and practice, (pp. 298-313). Chichester, UK: Wiley-Blackwell. 
Bond, F., Joda, L., \& Guenole, N. (2013). The work-related acceptance and action questionnaire (WAAQ): Initial psychometric findings and their implications for measuring psychological flexibility in specific contexts. Journal of Occupational and Organizational Psychology, 86(3), 331-347.

Borglum, K., \& Kubala, T. (2000). Academic and social integration of community college students: A case study. Community College Journal of Research \& Practice, 24, 567576. doi:10.1080/10668920050139712

Cartney, P., \& Rouse, A. (2006). The emotional impact of learning in small groups: Highlighting the impact on student progression and retention. Teaching in Higher Education, 11(1), 79-91.

Chawla, N., \& Ostafin, B. (2007). Experiential avoidance as a functional dimensional approach to psychopathology: An empirical review. Journal of Clinical Psychology, 63(9), 871890. doi:10.1002/jclp.20400

de Winter, J. C., \& Dodou, D. (2012). Factor recovery by principal axis factoring and maximum likelihood factor analysis as a function of factor pattern and sample size. Journal of Applied Statistics, 39(4), 695.

Deil-Amen, R. (2011). Socio-academic integrative moments: Rethinking academic and social integration among two-year college students in career-related programs. Journal of Higher Education Policy and Management, 82, 54-91. doi:10.1353/jhe.2011.0006

Eisenbeck, N. (2016). A brief acceptance and commitment therapy-based intervention among violence-prone male inmates delivered by novice therapists.(report). Psychology, Society, \& Education, 8(3), 1.

Flaxman, P., Bond, F., Livheim, F., \& Hayes, S. (Eds.). (2013). The mindful and effective employee: An acceptance and commitment therapy training manual for improving wellbeing and performance. Oakland: New Harbinger Publishers.

Freeman, M., deMarrais, K., Preissle, J., Roulston, K., \& St. Pierre, E. A. (2007). Standards of evidence in qualitative research: An incitement to discourse. Educational Researcher, 36(1), 25-32. doi:10.3102/0013189X06298009

Hagenauera, G., \& Voletb, S. E. (2014). Teacher-student relationship at university: An important yet under-researched field. Oxford Review of Education, 4(3), 370-388.

Hailikari, T., \& Parpala, A. (2014). What impedes or enhances my studying? the interrelation between approaches to learning, factors influencing study progress and earned credits. Teaching in Higher Education, 19(7), 812-824. doi:10.1080/13562517.2014.934348

Hailikari, T. \& Postareff, L. (2013). The relationship between university students' emotions and study pace. Paper presented in Earli conference, Munich, Germany $27^{\text {th }}$ to 31 th August.

Halawah, I. (2006). The impact of student-faculty informal interpersonal relationships on intellectual and personal development. College Student Journal, 40(3), 670-678.

Hayes, S. C., \& Smith, S. X. (cop. 2005). Get out of your mind \& into your life : The new acceptance \& commitment therapy. Oakland, CA: New Harbinger Publications.

Hayes, S., Luoma, J., Bond, F., \& Masuda, Akihiko,\& Lillis, Jason. (2006). Acceptance and commitment therapy: Model, processes, and outcomes. Behaviour Research and Therapy, 44(1), 1-25. 
Heikkilä, A., \& Lonka, K. (2006). Studying in higher education: Students' approaches to learning, self-regulation, and cognitive strategies. Studies in Higher Education, 31(1), 99-117. doi:10.1080/03075070500392433

Hirsto, L. (2012). Certainty of career choice at the beginning of university studies: General strategies and attributions in achievement situations. Studies for the Learning Society, 2(2-3), 35-45.

Holstein, J. A., \& Gubrium, J. F. (2004). The active interview. In D. Silverman (Ed.), Qualitative research: Theory, method and practice (2nd ed., pp. 140-161). London: Sage Publications Ltd.

Hunt, J., \& Eisenberg, D. (2010). Mental health problems and help-seeking behavior among college students. Journal of Adolescent Health, 46(1), 3-10. doi:http://dx.doi.org/10.1016/j.jadohealth.2009.08.008

Kashdan, T. B., \& Rottenberg, J. (2010). Psychological flexibility as a fundamental aspect of health. Clinical Psychology Review, 30(7), 865-878. doi:http://dx.doi.org/10.1016/j.cpr.2010.03.001

Lähteenoja, S. (2010). New students' integration to university studies [uusien opiskelijoiden integroituminen yliopistoon] (Doctoral dissertation). Available from $\mathrm{E}$ thesis.

Lee, Y., Choi, J., \& Kim, T. (2013). Discriminating factors between completers of and dropouts from online learning courses. British Journal of Educational Technology, 44(2), 328337. doi:10.1111/j.1467-8535.2012.01306.x

Nieminen, J., Asikainen, H. \& Hailikari, T. (2014). Appropriating the AAQ for the context of Stuyding. A Pilot Study among Students of Arts. Poster presented in ACBS World conference, Minneapolis, Minnesota, USA June 17-22.

OECD (2009). Education at a Glance 2009. OECD indicators. Report http://www.oecd.org/education/skills-beyond-school/43636332.pdf

Parpala, A., Lindblom-Ylänne, S., Komulainen, E., Litmanen, T., \& Hirsto, L. (2010). Students' approaches to learning and their experiences of the teaching-learning environment in different disciplines. British Journal of Educational Psychology, 80(2), 269-282.

Pascarella, E. T., \& Terenzini, P. T. (1980). Predicting freshman persistence and voluntary dropout decisions from a theorethical model. Journal of Higher Education, 51, 60-75.

Pascarella, E. T., \& Terenzini, P. T. (cop. 2005). How college affects students. a third decade of research / volume 2. San Francisco: Jossey-Bass.

Pascarella, E. T., Wolniak, G. C., \& Pierson, C. T. (2003). Explaining student growth in college when you don't think you are. Journal of College Student Development, 44(1), 122-126.

Pekrun, R., Goetz, T., Titz, W., \& Perry, R. P. (2002). Academic emotions in students' selfregulated learning and achievement: A program of qualitative and quantitative research. Educational Psychologist, 37(2), 91-105.

Pintrich, P. (2004). A conceptual framework for assessing motivation and self-regulated learning in college students. Educational Psychology Review, 16(4), 385-407. doi:10.1007/s10648-004-0006-X 
Postareff, L., Lindblom-Ylanne, S., \& Parpala, A. (2014). Explaining university students' strong commitment to understand through individual and contextual elements. Frontline Learning Research, 2(1), 31-49.

Räsänen, P., Lappalainen, P., Muotka, J., Tolvanen, A., \& Lappalainen, R. (2016). An online guided ACT intervention for enhancing the psychological wellbeing of university students: A randomized controlled clinical trial. Behaviour Research and Therapy, 78, 30-42. doi:http://dx.doi.org/10.1016/j.brat.2016.01.001

Schunk, D. H., \& Zimmerman, B. J. (Eds.). (2012). Motivation and self-regulated learning. theory, research and practice. New York: Routledge.

Sidelinger, R. J., Bolen, D. M., McMullen, A. L., \& Nyeste, M. C. (2015). Academic and social integration in the basic communication course: Predictors of students' out-of-class communication and academic learning. Communication Studies, 66(1), 63-84. doi:10.1080/10510974.2013.856807

Sloan, D. M. (2004). Emotion regulation in action: Emotional reactivity in experiential avoidance. Behaviour Research and Therapy, 42(11), 1257-1270. doi:http://dx.doi.org/10.1016/j.brat.2003.08.006

Storrie, K., Ahern, K., \& Tuckett, A. (2010). A systematic review: Students with mental health problems-A growing problem. International Journal of Nursing Practice, 16(1), 1-6. doi:10.1111/j.1440-172X.2009.01813.x

Tinto, V. (1975). Dropout from higher education: A theorethical synthesis of recent research. Review of Educational Research, 45(1), 89-125.

Tinto, V. (1993). Leaving college: Rethinking the causes and cures of student attrition (2nd ed.). Chicago, IL: The University of Chicago Press.

Vermunt, J. D. (1996). Metacognitive, cognitive and affective aspects of learning. Higher Education, 31(1), 25.

Vermunt, J. D., \& Van Rijswijk, F. (1988). Analysis and development of students' skill in selfregulated learning. Higher Education, 17, 647-682.

Vermunt, J. D., \& Verloop, N. (1999). Congruence and friction between learning and teaching. Learning and Instruction, 9(3), 257-280.

Won, S., Wolters, C. A., \& Mueller, S. A. (2017). Sense of belonging and self-regulated learning: Testing achievement goals as mediators. The Journal of Experimental Education, , 1-17. doi:10.1080/00220973.2016.1277337 